doi: 10.32620/oikit.2021.94.04

УДК 629.735.33-521

В.С. Долгих

\title{
Основні положення концепції створення безпілотної авіаційної транспортної системи
}

\author{
Національний аерокосмічний університет ім. М.Є. Жуковського \\ "Харківський авіаційний інститут»
}

Застосування безпілотних літальних систем знаходиться на початковій стадії, що характеризується значним рівнем розвитку безпілотних літальних апаратів та їх елементів, а також відсутністю підстав для застосування безпілотних літальних апаратів у реальних технологічних процесах. Вирішення цього протиріччя потребує вирішення різноманітних проблем концептуального, технічного, технологічного, методологічного, організаційно-правового та нормативного характеру.

Використання безпілотної авіаційної транспортної системи допомагає уникнути традиційних помилок, що виникають при пілотованому використанні авіаційної техніки виключаючи людський фрактор, сприяє прискоренню доставки вантажів, зменшує обсяги запасів товарно-матеріальних цінностей, підвищує продуктивність і ефективність перевезень.

Загалом сьогодні застосування безпілотних авіаційних систем у цивільній галузі практично обмежене окремими випадками місцевих застосувань на користь вирішення поточних виробничих або економічних проблем, головним чином, шляхом експериментальної процедури. Отже, очікується зростання ринку безпілотних літальних систем, що забезпечить можливість подолання ряду технічних та адміністративних бар'єрів, які обмежують використання безпілотних літальних систем у національному повітряному просторі. Слід також зазначити про все більше поширення безпілотних систем в загальному транспорті.

Метою цієї роботи було оцінювання основних положень концепції створення безпілотної авіаційної транспортної системи з погляду аеродинаміки, за ваговою досконалістю, міцністю, керуванням, системами літака, електронікою, експлуатаційною технологічністю, надійністю і безпекою, і показати, що такі вантажні безпілотники будуть конкурентоспроможними з великими пілотованими комерційними вантажними літаками, а також автомобільним транспортом.

Це дослідження було мотивовано зростаючим в усьому світі інтересом до безпілотних вантажних літаків. Воно було зосереджене, зокрема, на покращанні вантажних безпілотників порівняно з існуючими звичайними літаками загальної авіації, і це слід розглядати як попередній крок до комплексного оцінювання безпілотних вантажних транспортних систем.

Ключові слова: безпілотний літальний апарат (БПЛА), безпілотна авіаційна транспортна система (БАТС), аеродинаміка, вагова досконалість, міцність, керування, електроніка, експлуатаційна технологічність, надійність, безпека.

\section{Вступ}

Основною метою цієї концепції є відмова від пілотів на борту літака, забезпечення технічного рівня досконалості, що перевершує рівень кращих зарубіжних і вітчизняних пілотованих літаків аналогічного класу [1].

Досягнення зазначеної мети здійснюється на основі розроблених автором нових концепцій:

- за ваговою досконалістю - розроблення і створення конструкції планера і систем з ваговою віддачею з корисним навантаженням вище рівня літакових конструкцій пілотованих літаків;

- 3 погляду аеродинаміки - розроблення і створення аеродинамічного 
компонування безпілотного літака 3 крейсерською аеродинамічною якістю значно вище рівня, досягнутого пілотованим літакобудуванням;

- за міцністю - розроблення і створення конструкції планера і систем, яка при необхідній ваговій віддачі забезпечує ресурс вище або не менше показників пілотованих варіантів літаків;

- за керуванням - розроблення і створення автоматизованої багатоканальної електродистанційної системи керування літаком, яка не має аналогів у світовій практиці та забезпечує необхідний рівень надійності і безпеки польоту при малому ступені статичної стійкості;

- за системами літака - розроблення і створення багатоканальних і надійних систем енергопостачання, гідравлічних, систем керування механізацією, багатоопорних шасі та інших систем, що не мають аналогів в практиці пілотованого літакобудування;

- за електронікою - розроблення і створення принципово нових комплексів бортового обладнання, що забезпечують задані вимоги за пілотажними i навігаційними характеристиками 3 підвищенням точності числення порівняно з обладнанням пілотованих варіантів літаків;

- за експлуатаційною технологічністю, надійністю та безпекою розроблення і створення конструкції вантажної кабіни і завантажувальнорозвантажувального обладнання для забезпечення швидкого завантаження, вивантаження та безпечного перевезення техніки і вантажів.

\section{Основні переваги БАТС перед пілотованим варіантом літака}

Для забезпечення заданих характеристик основною перевагою безпілотного літака транспортної категорії порівняно з пілотованим варіантом стане відмова від цілого ряду систем. Більше немає необхідності в системах життєзабезпечення та устаткуванні, необхідному для пілотованого варіанта літака, а саме:

- системи кондиціонування повітря;

- системи підготовки повітря;

- системи автоматичного регулювання тиску;

- кисневого устаткування;

- побутового обладнання, до якого входить обладнання кабіни екіпажу;

- сантехнічне обладнання, крісла пілотів і т. д.

Вага таких систем для середнього транспортного літака становить 1,6 1,7 т, а це більше $6 \%$ від маси спорядженого літака.

Безпілотна авіаційна транспортна система (БАТС) потребує змінення в традиційній організації доставки вантажів авіаційним транспортом для забезпечення більшої ефективності. Це приводить до необхідності створення складів, які можуть бути використані як для тимчасового зберігання вантажів, так і для формування транспортних потоків, а також для пакетування вантажів під транспортний БПЛА.

БАТС являє собою замкнуту в межах своєї діяльності систему (тобто від оформлення замовлень або договорів на перевезення вантажів до відвантаження одержувачу або подальшому перевізнику), і $€$ складовою в глобальній транспортній системі з перевезення генеральних вантажів.

БАТС складається:

- $\quad$ з безпілотного транспортного літака для перевезення вантажів;

- системи керування польотом (керування зльотом і посадкою, 
контролювання крейсерського польоту, навігаційного забезпечення);

- системи технічного обслуговування і підтримки (технічне обслуговування і ремонт літака, технічне обслуговування і ремонт системи керування);

- системи оброблення вантажів (контроль складів вантажів, фрормування транспортних потоків);

- технічного матеріального забезпечення (пункти приймання вантажів, склади зберігання вантажів, пункти завантаження).

Розроблення принципово нової стратегії перевезення вантажів виконано з урахуванням забезпечення транспортного процесу 3 мінімальною участю людини і, як результат, виключенням людського фрактора. Стратегія забезпечення перевезень безпілотною транспортною системою орієнтована на оптимальний розмір і вагу вантажів.

Треба врахувати також змінення структури перевезених вантажів для реалізації принципів БТС і самих стратегій майбутнього, змінення структури всіх рівнів апарату керування і регламентації завдань (транспортних підрозділів фрірм). Виходячи зі стратегії логістики і виробництва в ланцюжках транспортних потоків, нова стратегія перевезення вантажів має бути органічною складовою в ієрархії стратегії підприємства, яке використовує її в своїх перевезеннях.

Основні положення логістики, характерні для фрірм-виробників і споживачів продукції (пріоритет споживача, високий рівень сервісу, скорочення часу виконання замовлень та ін.) повною мірою належать і до підприємств транспортного напрямку, залучених до логістичної системи.

Відмінністю їх роботи в нових умовах конкуренції на ринку транспортних послуг $€$ визначення політики комплексного вирішення транспортних i пов'язаних з ними проблем на іншому, якісно високому рівні порівняно 3 пілотованими аналогами даної системи.

Практика показує, що така політика $є$ успішною, коли вона $є$ досить диференційованою і базується на таких основних компонентах, як надання нових, нетрадиційних додаткових послуг політики укладання контрактів у сорері комунікацій. До політики надання послуг належать всі рішення і дії, спрямовані на комплексне здійснення транспортного процесу. Це означає, що організація перевезень вантажів з урахуванням відстані його транспортування, кількості та термінів доставки планується в комплексі з додатковими послугами виходячи 3 потреб попиту.

Як показує досвід, транспортні підприємства охоче розширюють диверсифікацію своєї діяльності, це підвищує потенціал залучення клієнтури, збільшує прибуток, прискорює впровадження нових транспортних технологій, зміцнення позицій на ринку транспортних послуг. У свою чергу, фрірмипродуценти не менше зацікавлені в тому щоб звільнитися від багатьох логістичних функцій і зосередитися на основних профрілюючих видах діяльності з метою зниження витрат і підвищення гнучкості в роботі.

Чи йде мова про звичайну відправку вантажу авіатранспортом, митне очищення або глобальні логістичні концепції - БАТС повинна стати кращим рішенням для регіональних або міжнародних логістичних напрямків перевезення вантажів.

БАТС підвищить прибуток транспортних компаній від вантажоперевезень, при цьому запровадить, безпечність та надійність перевезення вантажів на 
підготовлені аеродроми по всьому світу.

БАТС повинна забезпечувати:

- $\quad$ міжнародну транспортну мережу на всіх підготовлених вантажних аеропортах в усьому світі;

- партнерські відносини 3 найбільш надійними вантажними авіакомпаніями по всьому світу;

- $\quad$ широкий спектр послуг у сфрері відправлення вантажів повітряним транспортом ;

- оптимальну комбінацію мультимодальних транспортних перевезень.

Сегмент авіаперевозок вантажів $є$ частиною сфери діяльності безпілотної транспортної системи, яка пропонує комплексні рішення для пересилання вантажів повітряним шляхом.

При використанні такої системи можна отримати всебічний сервіс 3 вантажних авіаперевезень від вивезення товару до його доставки за місцем призначення. При цьому БАТС може знизити витрати авіаперевезень і забезпечити конкурентоспроможність стосовно цін.

Можливості БАТС у сорері вантажних авіаперевезень:

- доставка вантажів за мінімальної участі людини;

- $\quad$ спроможність працювати на генеральних транспортних потоках;

- забезпечення мінімального часу при обробленні і доставці вантажів;

- зберігання на складі та дистрибуція;

- економія при перевезенні невеликих відправлень завдяки їх консолідації;

- Tracking \& Tracing (система відстеження вантажів у реальному масштабі часу через Інтернет).

БАТС має надавати також весь спектр послуг з доставки - від митного оформлення до кінцевого транспортування до місця призначення. Приймати і відправляти вантажі в усіх підготовлених аеропортах світу і знаходити оптимальні маршрути між пунктами доставки в усьому світі.

БАТС повинна здійснювати вантажні авіаперевезення на більш високому якісному рівні порівняно з пілотованою авіацією:

- $\quad$ щорічний відсоток збитку має бути менше порівняно з пілотованою авіацією;

- $\quad$ конкурентоспроможні умови;

- більш короткий час пересилання порівняно 3 традиційним пілотованим авіаційним перевезенням вантажів;

- пропонування більш високої щільності польотів і постійної можливості планування пропускної здатності.

БАТС повинна використовувати мінімальний маршрут доставки вантажів, при цьому спираючись на всебічну систему керування якістю, яка застосовується там, де це необхідно. Наприклад, перевезення по території третіх країн і комплексні доставки вантажів від дверей до дверей.

БАТС буде ефективною на генеральних авіаперевезеннях, коли потрібна швидкість при доставці вантажів в найбільш завантажених вантажних потоках між країнами і на інші континенти.

Для фірм, що займаються перевезеннями, необхідним $€$ виконання функцій контролю за вантажами під час перевезення, зберігання продукції на 
складах транспортних підприємств, розроблення маршрутів доставки товарів. Для транспортних підприємств необхідний електронний обмін даними між учасниками логістичного процесу і зберігання інформації.

Досвід більшості транспортних фрірм показує, що політика додаткових послуг, не пов'язаних з перевезеннями, дає позитивні результати. Вона підвищує потенціал залучення клієнтури, збільшує прибуток, дозволяє прискорити втілення більш прогресивних транспортних технологій і поліпшення обслуговування споживачів, які постійно контактують з перевізниками, зміцнює їхнє становище на ринку транспортних послуг.

На думку деяких експертів-логістів, основною причиною, яка перешкоджає розширенню взаємодій промислових і транспортних фрірм у сфері логістики, $є$ небезпека втрати вантажовласником контролю за перевезенням сировини і готової продукції. Разом з тим слід зазначити, що ця причина суб'єктивного характеру і її вплив буде зменшуватися в міру накопичення досвіду роботи і зміцнення довіри.

Політика транспортних підприємств в області комунікацій має на меті інформування клієнтів про передбачувані пакети послуг, постійно впливати на клієнтуру, щоб вона користувалася їх послугами в якомога ширшому обсязі. Інша мета цієї політики - стимулювання поширення і вдосконалення взаємодії транспортних фрірм 3 вантажовідправниками на основі використання комп'ютерної техніки, головним чином через електронний обмін інформацією.

Інфрормування клієнтів про можливість запропонувати пакети послуг означає не тільки постійний зв'язок з ними, а й переосмислення самої політики вантажоперевезень. Якщо збут транспортних послуг все більше завойовує ринок покупців, а не продавців, ця вимога має бути провідною і в періоди обмеження транспортних потужностей, оскільки прагнення збути послуги пролонговане у часі.

Крім того, для збуту послуг необхідна ще одна важлива умова: інформація повинна оновлюватися. Можуть уводитися нові маршрути або новий спосіб перевезень, що сприяє підвищенню ступеня визначеності пропонованого пакета послуг. Таким чином, політика в області комунікацій повинна переконати ринок, щоб визначити групи клієнтури особливої значущості щодо пропонованих послуг і можливої їх стабільності.

Пропозиції пакета транспортних послуг передує вивчення потреб клієнтури. В останні роки на транспорті дослідженням потреб у послугах почали займатися спеціальні логістичні центри, які аналізують вантажопотоки і їх розподіл по мережі. Після аналізу розробляють пропозиції щодо організації оптимальних вантажопотоків авіаційним, а також іншими видами транспорту, а також щодо способів розподілу перевезень між різними видами транспорту, комплектування групи товарів, порядку укладення договорів на перевезення та ін. Мета даної концепції - забезпечити підвищення рівня ефективності роботи транспорту порівняно з пілотованим варіантом перевезення по повітрю, а також дотримання термінів доставки вантажів, підвищення надійності та регулярності перевезень.

Заслуговує на увагу перегрупування вантажів на вантажопотоки за допомогою безпілотної транспортної системи 3 метою підвищення рентабельності перевезень завдяки укрупненню вантажопотоку і впровадженню деяких операцій. Концентрацію вантажопотоків стимулює тарифна політика, завдяки якій масові перевезення вантажів здійснюються за зниженими 
тарифами. При цьому місце перегрупування вантажопотоків може використовуватися одним або декількома підприємствами.

\section{Висновки і перспективи}

Застосування безпілотних літальних систем знаходиться на початковій стадії, що характеризується значним рівнем розвитку безпілотних літальних апаратів та їх елементів, а також відсутністю підстав для застосування безпілотних літальних апаратів у реальних технологічних процесах. Вирішення цього протиріччя потребує вирішення різноманітних проблем концептуального, технічного, технологічного, методологічного, організаційно-правового і нормативного характеру.

Використання безпілотної авіаційної транспортної системи допомагає уникнути традиційних помилок, що виникають при пілотованому використанні авіаційної техніки виключаючи людський фрактор, сприяє прискоренню доставки вантажів, зменшує обсяги запасів товарно-матеріальних цінностей, підвищує продуктивність і ефрективність перевезень.

Загалом сьогодні застосування безпілотних літальних систем у цивільній галузі практично обмежується окремими випадками місцевих застосувань на користь вирішення поточних виробничих або економічних проблем, головним чином шляхом експериментальної процедури. Отже, зростання ринку безпілотних літальних систем, як очікується, забезпечить можливість ряду технічних та адміністративних бар'єрів, що обмежують використання безпілотних літальних систем у національному повітряному просторі.

Це дослідження слід розглядати як попередній крок до комплексного оцінювання та оптимізації вимог до БАТС, включаючи сам літак, наземну інфрраструктуру, експлуатацію тощо.

\section{Список літератури}

1. Харченко, Владимир. Анализ применения беспилотных авиационных систем гражданского назначения / Владимир Харченко, Дмитрий Прусов. - Киев : 2012. - C. 118 - 130.

2. Hasan, Yasim. Preliminary design study for a future unmanned cargo aircraft configuration / Yasim J. Hasan, Falk Sachs, Johann C. Dauer. / CEAS Aeronautical Journal, 9(4) 571-86 - 2018. - P. 61 - 74.

3. Burzlaff, Marcus. Aircraft Fuel Consumption - Estimation and Visualization. / Marcus Burzlaff. Hamburg University of Applied Sciences. - Hamburg, 2001. P. $47-63$.

4. Flightpath 2050, Europe's vision for aviation: maintaining global leadership and serving society's needs. / S. Kallas, M. Geoghegan-Quinn, M. Darecki, C. Edelstenne, T. Enders, E. Fernandez, P. Hartman. - Report of the European commission No. EUR 98. - Brussels, Belgium, 2011. - P. $44-52$.

5. Energy efficiency optimization in UAVs: a review / Eleftherios Amoiralis, Marina A. Tsili, Vassilios Spathopoulos, Antonios Hatziefremidis. Materials Science Forum, Vol. 792. - 2014. - P. 117 - 131.

6. Valerdi, Ricardo. Cost metrics for unmanned aerial vehicles. Infotech@ Aerospace. Session: I@A-68: UAV Systems - Issues \& Technologies. September 26-29, 2005. - https://doi.org/10.2514/6.2005-7102. 
7. Energy use and life cycle greenhouse gas emissions of drones for commercial package delivery. / Joshuah K. Stolaroff, Constantine Samaras, Emma R. O'Neill, Alia Lubers, Alexandra S. Mitchell, Daniel Ceperley. Nature communications 9. Article No. 409 - 2018. - P. $41-49$.

8. Timothy R. Gulden. The Energy Implications of Drones for Package Delivery: A Geographic Information System Comparison. - 2017. https://doi.org/10.7249/RR1718.1.

9. Collins Mark Patrick. The Future Market for Large Unmanned Cargo Aircraft in the National Airspace System. Unmanned Cargo Aircraft Conference. March, 20, 2018.

https://www.platformuca.org/wp-content/uploads/2018/01/LUCA-market-researchthesis-by-Mark-Patrick-Collins-v7.pdf.

10. Rian, Van Groningen. Cost Benefit Analysis Unmanned Cargo Aircraft: Case Study Stuttgart - Urumqi/Shenzen. - https://www.platformuca.org/wpcontent/uploads/2017/01/Groningen2017-Business-case-UCA-China-Europe.pdf.

11. Historical and Future Trends in Aircraft Performance, Cost, and Emissions / Joosung J. Lee, Stephen P. Lukachko, lan A. Waitz, Andreas Schafer. https://www.annualreviews.org/doi/abs/10.1146/annurev.energy.

12. Peeters P. M., Middel J., Hoolhorst A. Fuel efficiency of commercial aircraft: an overview of historical and future trends / https://www.transportenvironment.org/discover/fuel-efficiency-commercial-aircraftoverview-historical-and-future-trends/.

\section{References}

1. Harchenko, Vladimir. Analiz primenenija bespilotnyh aviacionnyh sistem grazhdanskogo naznachenija [Analysis of the use of civil unmanned aerial systems] / Vladimir Harchenko, Dmitrij Prusov. - Kiev : 2012. - P. 118 - 130.

2. Hasan, Yasim. Preliminary design study for a future unmanned cargo aircraft configuration / Yasim J. Hasan, Falk Sachs, Johann C. Dauer. / CEAS Aeronautical Journal, 9(4) 571-86 - 2018. - P. 61 - 74.

3. Burzlaff, Marcus. Aircraft Fuel Consumption - Estimation and Visualization. / Marcus Burzlaff. Hamburg University of Applied Sciences. - Hamburg, 2001. P. $47-63$.

4. Flightpath 2050, Europe's vision for aviation: maintaining global leadership and serving society's needs. / S. Kallas, M. Geoghegan-Quinn, M. Darecki, C. Edelstenne, T. Enders, E. Fernandez, P. Hartman. - Report of the European commission No. EUR 98. - Brussels, Belgium, 2011. - P. $44-52$.

5. Energy efficiency optimization in UAVs: a review / Eleftherios Amoiralis, Marina A. Tsili, Vassilios Spathopoulos, Antonios Hatziefremidis. Materials Science Forum, Vol. 792. - 2014. - P. 117 - 131.

6. Valerdi, Ricardo. Cost metrics for unmanned aerial vehicles. Infotech@ Aerospace. Session: |@A-68: UAV Systems - Issues \& Technologies. September 26-29, 2005. - https://doi.org/10.2514/6.2005-7102.

7. Energy use and life cycle greenhouse gas emissions of drones for commercial package delivery. / Joshuah K. Stolaroff, Constantine Samaras, Emma R. O'Neill, Alia Lubers, Alexandra S. Mitchell, Daniel Ceperley. Nature communications 9. Article No. 409 - 2018. - P. $41-49$. 
8. Timothy R. Gulden. The Energy Implications of Drones for Package Delivery: A Geographic Information System Comparison. - 2017. https://doi.org/10.7249/RR1718.1.

9. Collins Mark Patrick. The Future Market for Large Unmanned Cargo Aircraft in the National Airspace System. Unmanned Cargo Aircraft Conference. March, 20, 2018.

https://www.platformuca.org/wp-content/uploads/2018/01/LUCA-market-researchthesis-by-Mark-Patrick-Collins-v7.pdf.

10. Rian, Van Groningen. Cost Benefit Analysis Unmanned Cargo Aircraft: Case Study Stuttgart - Urumqi/Shenzen. - https://www.platformuca.org/wpcontent/uploads/2017/01/Groningen2017-Business-case-UCA-China-Europe.pdf.

11. Historical and Future Trends in Aircraft Performance, Cost, and Emissions / Joosung J. Lee, Stephen P. Lukachko, lan A. Waitz, Andreas Schafer. https://www.annualreviews.org/doi/abs/10.1146/annurev.energy.

12. Peeters P. M., Middel J., Hoolhorst A. Fuel efficiency of commercial aircraft: an overview of historical and future trends / https://www.transportenvironment.org/discover/fuel-efficiency-commercial-aircraftoverview-historical-and-future-trends/.

Надійшла до редакції 18.12.2021, розглянута на редколегії 19.12.2021.

\section{Основные положения концепции создания беспилотной авиационной транспортной системы}

Применение беспилотных летательных систем находится на начальной стадии, что характеризуется значительным уровнем развития беспилотных летательных аппаратов и их элементов, а также отсутствием оснований для применения беспилотных летательных аппаратов в реальных технологических процессах. Разрешение этого противоречия требует решения различных проблем концептуального, технического, технологического, методологического, организационно-правового и нормативного характера.

Использование беспилотной авиационной транспортной системы помогает избежать традиционных ошибок, возникающих при пилотируемом использовании авиационной техники, исключая человеческий фрактор, способствует ускорению доставки грузов, уменьшает объемы запасов товарноматериальных ценностей, повышает производительность и эффрективность перевозок.

В целом сегодня применение беспилотных авиационных систем в гражданской отрасли практически ограничено частными случаями местных применений в пользу решения текущих производственных или экономических проблем, главным образом путем экспериментальной процедуры. Следовательно, ожидается рост рынка беспилотных летательных систем, что позволит преодолеть ряд технических и административных барьеров, ограничивающих использование беспилотных летательных систем в национальном воздушном пространстве. Следует отметить все большее распространение беспилотных систем в общем транспорте.

Целью данной работы было оценить основные положения концепции 
создания беспилотной авиационной транспортной системы с точки зрения аэродинамики, по весовому совершенству, прочности, управлению, системам самолета, электронике, эксплуатационной технологичности, надежности и безопасности и показать, что такие грузовые беспилотники будут конкурентоспособными с крупными пилотируемыми коммерческими грузовыми самолетами, а также автомобильным транспортом.

Это исследование было мотивировано растущим во всем мире интересом к беспилотным грузовым самолетам. Она была сосредоточена, в частности, на улучшении грузовых беспилотников по сравнению с существующими обычными самолетами общей авиации, и это следует рассматривать как предварительный шаг к комплексной оценке беспилотных грузовых транспортных систем.

Ключевые слова: беспилотный летательный аппарат (БПЛА), беспилотная авиационная транспортная система (БАТС).

\section{The basic the provisions of the concept of creation of unmanned aircraft transport system}

The use of unmanned aerial vehicles is at an early stage, which is characterized by a significant level of development of unmanned aerial vehicles and their elements, as well as the lack of grounds for the use of unmanned aerial vehicles in real technological processes. The resolution of this contradiction requires the solution of various problems of a conceptual, technical, technological, methodological, organizational, legal and regulatory nature.

The use of an unmanned aviation transport system helps to avoid the traditional mistakes that arise during the manned use of aviation technology, eliminating the human factor, helps to accelerate the delivery of goods, reduces the amount of inventory of goods and materials, and increases the productivity and efficiency of transportation.

In general, today the use of unmanned aircraft systems in the civilian industry is practically limited to special cases of local applications in favor of solving current industrial or economic problems, mainly through an experimental procedure. Consequently, the market for unmanned aerial systems is expected to grow, which will overcome a number of technical and administrative barriers that restrict the use of unmanned aerial systems in national airspace. It should be noted the increasing spread of unmanned systems in public transport.

The purpose of this work was to assess the main provisions of the concept of creating an unmanned aviation transport system from the point of view of aerodynamics, in terms of weight perfection, in terms of strength, in control, in aircraft systems, in electronics, in operational manufacturability, reliability and safety, and to show that such cargo drones will competitive with large manned commercial cargo planes and road transport.

This research was motivated by the growing worldwide interest in unmanned cargo aircraft. It focused in particular on improving cargo drones over existing conventional general aviation aircraft, and this should be seen as a preliminary step towards a comprehensive assessment of unmanned cargo transport systems.

Key words: unmanned aerial vehicle (UAV), unmanned aerial transport system (UATS). 


\section{Відомості про авторів:}

Долгих В'ячеслав Сергійович - аспірант кафедри 103 «Проектування літаків і вертольотів», Національний аерокосмічний університет ім. М. $€$. Жуковського «Харківський авіаційний інститут», Україна, Україна. e-mail: dolhykh@gmail.com, ORCID 0000-0002-0305-2370

\section{About the Authors:}

Viacheslav Dolhykh - post-graduate student of the Department of Airplanes and Helicopters Design, National Aerospace University named after M. E. Zhukovsky "Kharkiv Aviation Institute", Kiev, Ukraineю e-mail: dolhykh@gmail.com, ORCID 0000-0002-0305-2370. 